Jurnal Media Pertanian Vol. 3 No. 1 Tahun 2018 Hal. 24 - 31

Media Komunikasi Hasil Penelitian dan Review Literatur Bidang Ilmu Agronomi ISSN print $2503-1279$ ISSN online $2581-1606$

\title{
INVENTARISASI PENYAKIT YANG DISEBABKAN JAMUR \\ PADA TANAMAN KELAPA DALAM (Cocos nucifera L.) DI DESA SUNGAI JERENG KECAMATAN PENGABUAN KABUPATEN TANJUNG JABUNG BARAT
}

\author{
Yuza Defitri ${ }^{1)}$ dan Sulaiman ${ }^{2)}$ \\ ${ }^{1)}$ Program studi Agroteknologi, Fakultas Pertanian Universitas Batanghari \\ 2) Alumni Program studi Agroteknologi, Fakultas Pertanian Universitas Batanghari \\ J1. Slamet Riyadi-Broni, Jambi. 36122. Telp. +62074160103 \\ ${ }^{1)}$ Email korespondensi : yuzadefitri1968@gmail.com
}

\begin{abstract}
The purpose of this study was to find out the inventory of disease caused by fungus in the coconut plants. This research was conducted in community owned garden located in Sungai Jereng Village, Pengabuan District of Tanjung Jabung Barat Regency. The material used in this study is the coconut plant samples in which the disease is present in the community plantation land with the method of simple random sampling and the observed object is a fungus that causes diseases in microscopic in the Laboratory of Agricultural Quarantine Class 1 Jambi.Field observation results and laboratory observations showed that two pathogens that Pestalotiopsis and Fusarium attacked the coconut plant in Sungai Jereng Village Pengabuan District of Tanjung Jabung Barat District.
\end{abstract}

Keywords: disease, fungus, coconut plant

Abstrak
Tujuan penelitian ini adalah untuk melakukan inventarisasi penyakit yang disebabkan jamur pada tanaman kelapa dalam. Penelitian ini dilaksanakan di kebun milik rakyat yang berada di Desa Sungai Jereng Kecamatan Pengabuan Kabupaten Tanjung Jabung Barat. Bahan yang digunakan dalam penelitian ini adalah sampel tanaman kelapa dalam yang terserang penyakit dengan metode pengambilan sampel simple random sampling dan objek yang diamati adalah jamur yang mengakibatkan penyakit pada tanaman kelapa dalam secara mikroskopik di laboratorium Karantina Pertanian Kelas 1 Jambi. Hasil pengamatan lapangan dan pengamatan laboratorium menunjukkan bahwa ditemukan dua patogen yaitu Pestalotiopsis sp dan Fusarium sp yang menyerang tanaman kelapa dalam di Desa Sungai Jereng Kecamatan Pengabuan Kabupaten Tanjung Jabung Barat.

Kata Kunci: Penyakit, Jamur, kelapa dalam

\section{PENDAHULUAN}

Kelapa (Cocos nucifera L.) merupakan komoditi strategis yang memiliki peran sosial, budaya dan ekonomi dalam kehidupan masyarakat Indonesia. Manfaat tanaman tidak saja terletak pada daging buahnya yang dapat diolah menjadi santan, kopra dan minyak santan, tetapi seluruh bagian tanaman kelapa mempunyai manfaat yang besar. Demikian besar manfaat tanaman kelapa sehingga ada yang menamakannya. sebagai pohon kehidupan (the tree of life)

Diterbitkan oleh Program Studi Agroteknologi Fakultas Pertanian Universitas Batanghari Jambi Halaman 24 
Jurnal Media Pertanian Vol. 3 No. 1 Tahun 2018 Hal. 24 - 31

Media Komunikasi Hasil Penelitian dan Review Literatur Bidang Ilmu Agronomi ISSN print $2503-1279$ ISSN online $2581-1606$

atau pohon yang amat menyenangkan (a heavan tree). Kelapa merupakan tanaman tropis yang telah lama dikenal masyarakat Indonesia (Ruauw, Baroleh dan Powa, 2011 ).

Indonesia memiliki potensi sumber daya lahan yang cukup luas dan belum dimanfaatkan secara optimal. Total luas dataran Indonesia sekitar 192 juta hektar, terbagi atas 123 juta hektar $(64,6 \%)$ kawasan budidaya dan 67 juta hektar sisanya $(35,4 \%)$ merupakan kawasan lindung. Ketersedian lahan tersebut menjadi salah satu keunggulan komparatif dalam perkembangan komoditas perkebunan. Perkembangan areal perkebunan cukup pesat, yaitu dari 17,19 juta hektar pada tahun 2003 menjadi 21,54 juta hektar pada tahun 2013. Saat ini masih tersedia lahan potensial untuk perkembangan komoditas perkebunan sekitas 24 juta hektar yang meliputi lahan berpotensial baik (18,74 juta hektar), lahan berpotensi sedang (2,99 juta hektar), dan sisanya lahan berpotensi bersyarat, seperti lahan rawa dan gambut yang masih memerlukan inovasi teknologi untuk pengembangannya (Yudirachman,2016).

Kabupaten Tanjung Jabung Barat dengan luas areal perkebunan kelapa dalam 54.441 hektar atau sekitar 45,99 persen dari total luas areal tanaman kelapa Provinsi Jambi dengan jumlah produksi sebesar 54.766 ton. Bagi sebagian besar masyarakat daerah Kabupaten Tanjung Jabung Barat, perkebunan kelapa dalam merupakan salah satu komoditi perkebunan yang penting dan merupakan sumber penghasilan utama yang dikelola secara intensif, sehingga ketergantungan petani terhadap perkebunan kelapa sangat tinggi. Luas areal tanaman kelapa terbesar terdapat di Kecamatan Pengabuan, pada tahun 2014 mencapai 13.510 hektar atau $24,82 \%$ dari luas seluruh tanaman kelapa, dengan jumlah produksi sebesar 13.564 ton, Kecamatan Senyerang yang memiliki luas areal tanaman kelapa sebesar 11.013 hektar atau 20,22\% dari luas seluruh tanaman kelapa dengan jumlah produksi sebesar 10.254 ton serta Kecamatan Kuala Betara dengan luas areal tanaman kelapa mencapai 9.224 hektar atau $16,94 \%$ dari luas seluruh tanaman kelapa, dengan jumlah produksi sebesar 10.824 ton (Dinas Pekebunan Tanjung Jabung Barat,2014).

Salah satu masalah yang ditemukan di pertanaman kelapa kelapa dalam yaitu adanya serangan beberapa penyakit, antara lain gugur buah (premature nutfall), yang disebabkan oleh jamur Phytophthora palmivora. Penyakit karat batang atau batang berdarah (Stem bleeding), disebabkan oleh jamur Ceratocystis paradoxa (Dade) Moreau, bercak daun (Gray leaf spot) disebabkan oleh jamur Pestalotiopsis palmarum (Cke) Stey dan busuk tunas pra-tumbuh (Pre-emergant shoot rot) disebabkan oleh jamur Marasmius palmivorus Sharples (Semangun, 1991).

\section{METODOLOGI PENELITIAN}

Penelitian ini dilakukan di areal perkebunan kelapa dalam rakyat di Desa Sungai Jereng, Kecamatan Pengabuan, Kabupaten Tanjung Jabung Barat, Provinsi Jambi, serta Laboratorium Karantina Pertanian Kelas 1 Jambi mulai bulan Oktober sampai bulan Desember 2017.

Bahan yang digunakan dalam penelitian ini adalah sampel bagian tanaman kelapa dalam yang terserang penyakit pada lahan perkebunan masyarakat, 
Jurnal Media Pertanian Vol. 3 No. 1 Tahun 2018 Hal. 24 - 31

Media Komunikasi Hasil Penelitian dan Review Literatur Bidang Ilmu Agronomi ISSN print $2503-1279$ ISSN online $2581-1606$

alkohol, chlorox, air aquades, kertas saring, dan koran. Alat yang digunakan dalam penelitian ini meliputi pisau, plastik, alat tulis, kamera, petridish, airstream, gunting, pinset, buku indentifikasi jamur dan miskroskop.

Metode pengambilan sampel menggunakan metode SRS (simple random sampling) jika jumlah populasi tanaman dan jumlah petani lebih dari 100 maka tanaman sampel sebanyak $15 \%$ sedangkan jika jumlah populasi tanaman kurang dari 100 maka tanaman sampel sebanyak 50\% (Tasri, 2007). Lokasi yang dijadikan sampel adalah F1 (lahan 1), F2 (lahan 2), F3 (lahan 3) dengan jumlah tanaman setiap lokasi sebanyak 20 pohon.

Pengambilan sampel dilakukan di kebun kelapa dalam yang telah menghasilkan, untuk 1 desa dipilih 3 kebun secara acak. Masing-masing areal dilakukan pengamatan terhadap tanaman kelapa dalam yang terserang penyakit, kemudian dari tanaman yang menunjukkan gejala penyakit dilakukan indentifikasi jamur di laboratorium.

Data yang dikumpulkan adalah data primer dan data sekunder. Data primer merupakan hasil pengamatan secara langsung terhadap tanaman kelapa dalam dengan mengamati gejala luar di lapangan serta hasil wawancara dengan petani setempat. Sedangkan data sekunder adalah beberapa informasi yang diperoleh dari intansi yang terkait dengan penelitian ini.

Pelaksanaan penelitian di lapangan adalah mengamati tanaman kelapa dalam yang menunjukkan gejala serangan penyakit jamur, seperti busuk janur (fusarium sp), penyakit bercak daun (Gray leaf spot), busuk buah (premature nutfall), layu natuna dan masing-masing bagian tanaman yang menunjukkan gejala serangan penyakit tersebut diamati secara makroskopis. Sampel tanaman yang terserang penyakit diambil kemudian dibungkus dengan kertas koran lembab dan dimasukkan ke dalam kantong plastik, kemudian disimpan dalam kulkas sampai saatnya untuk diidentifikasi.

Jamur dari bagian tanaman diisolasi di laboratorium dengan cara Moist chamber. Sampel tanaman dipotong persegi empat kecil-kecil kira-kira $1 \mathrm{~cm}$, kemudian dibilas dengan aquades, lalu disterilkan dengan chlorox $0,1 \%$ selama kurang lebih 1-3 menit. Potongan tersebut diambil dengan menggunakan pinset dan dicuci dengan aquades dan diletakkan diatas kertas saring lembab dalam petridish kemudian diinkubasi selama kurang lebih 7x24 jam. Setelah itu diamati dengan miskroskop untuk mengindentifikasi jamur-jamur yang menyerang tanaman kelapa dalam dengan mengunakan buku indentifikasi jamur.

Data yang diperoleh berupa gejala-gejala penyakit pada tanaman kelapa dalam dan jamur patogen penyebab penyakit, dianalisis secara deskriptif.

\section{Pengamatan Lapangan}

Hasil pengamatan di lapangan ditemukan beberapa gejala penyakit yang disebabkan jamur. Jumlah tanaman terserang dan persentase serangan dapat dilihat pada Tabel 1.

Diterbitkan oleh Program Studi Agroteknologi Fakultas Pertanian Universitas Batanghari Jambi Halaman 26 
Jurnal Media Pertanian Vol. 3 No. 1 Tahun 2018 Hal. 24 - 31

Media Komunikasi Hasil Penelitian dan Review Literatur Bidang Ilmu Agronomi ISSN print $2503-1279$ ISSN online $2581-1606$

Tabel 1. Jenis, gajala serta persentase serangan penyakit yang menyerang tanaman kelapa dalam di Desa Sungai Jereng Kecamatan Pengabuan.

\begin{tabular}{|c|c|c|c|c|c|c|}
\hline \multirow[t]{2}{*}{ No } & \multirow{2}{*}{$\begin{array}{l}\text { Jenis } \\
\text { Penyakit }\end{array}$} & \multirow[t]{2}{*}{ Gejala } & \multicolumn{3}{|c|}{$\begin{array}{l}\text { Jumlah dan Persentasi Tanaman } \\
\text { Terserang Penyakit }\end{array}$} & \multirow[t]{2}{*}{ Patogen } \\
\hline & & & $\mathrm{F}_{1}$ & $\mathrm{~F}_{2}$ & $\mathrm{~F}_{3}$ & \\
\hline 1 & $\begin{array}{l}\text { Busuk } \\
\text { Buah }\end{array}$ & $\begin{array}{l}\text { Pada kulit } \\
\text { (epikarpium) terjadi } \\
\text { bercak kecil, berwarna } \\
\text { coklat muda kebasah } \\
\text { basahan, dengan garis } \\
\text { tengah lebih kurang } 1 \\
\text { cm, biasanya pada } \\
\text { pertengahan antara } \\
\text { ujung dan pangkal } \\
\text { buah. }\end{array}$ & $\begin{array}{l}3 \text { pohon } \\
15 \%\end{array}$ & $\begin{array}{l}4 \text { pohon } \\
20 \%\end{array}$ & $\begin{array}{l}1 \text { pohan } \\
5 \%\end{array}$ & Fusarium, sp \\
\hline 2 & $\begin{array}{l}\text { Layu } \\
\text { Natuna }\end{array}$ & $\begin{array}{l}\text { Mula-mula daun-daun } \\
\text { tengah layu, } \\
\text { menguning dan } \\
\text { akhirnya mati. Pada } \\
\text { bunga terjadi } \\
\text { pembusukan, dan } \\
\text { buah-rontok rontok }\end{array}$ & $\begin{array}{l}5 \text { pohon } \\
25 \%\end{array}$ & $\begin{array}{l}5 \text { pohon } \\
25 \%\end{array}$ & $\begin{array}{l}2 \text { pohon } \\
10 \%\end{array}$ & Fusarium, sp \\
\hline 3 & $\begin{array}{l}\text { Bercak } \\
\text { Daun }\end{array}$ & $\begin{array}{l}\text { Pada daun mula-mula } \\
\text { terjadi bercak-bercak } \\
\text { yang tembus cahaya, } \\
\text { yang segera menjadi } \\
\text { coklat kekuningan, dan } \\
\text { tepi coklat tua. }\end{array}$ & $\begin{array}{l}7 \text { pohon } \\
35 \%\end{array}$ & $\begin{array}{l}10 \text { pohon } \\
50 \%\end{array}$ & $\begin{array}{l}12 \text { pohon } \\
60 \%\end{array}$ & Pestalotiopsis, sp \\
\hline 4 & $\begin{array}{l}\text { Busuk } \\
\text { Janur }\end{array}$ & $\begin{array}{l}\text { Pertama tampak pada } \\
\text { janur atau daun muda } \\
\text { yang baru saja } \\
\text { membuka, berupa } \\
\text { bercak berbentuk garis } \\
\text { berwarna ungu tua } \\
\text { atau coklat tua. }\end{array}$ & $\begin{array}{l}6 \text { pohon } \\
30 \%\end{array}$ & $\begin{array}{l}4 \text { pohon } \\
20 \%\end{array}$ & $\begin{array}{l}5 \text { pohon } \\
25 \%\end{array}$ & Fusarium, sp \\
\hline
\end{tabular}

Ket: $F_{1}, F_{2}$ dan $F_{3}$ Lokasi pengambilan sampel.

Berdasarkan Tabel 1, jenis penyakit yang ditemukan pada seluruh lahan yang diamati ada empat penyakit yaitu busuk buah, layu natuna, bercak daun dan busuk janur. Penyakit busuk buah yang diakibatkan oleh jamur Fusarium, sp pada lahan satu (F1) terdapat 3 pohon (15\%) tanaman yang terserang penyakit jamur,pada lahan dua (F2) terdapat 4 pohon (20\%) dan pada lahan tiga (F3) terdapat 1 pohon $(5 \%)$. Penyakit layu natuna yang diakibatkan oleh jamur Fusarium, sp pada lahan satu (F1) terdapat 5 pohon (25\%), pada lahan dua (F2) terdapat 5 pohon $(25 \%)$, pada lahan tiga (F3) terdapat 2 pohon $(10 \%)$. Penyakit bercak daun yang diakibatkan oleh jamur Pestalotiopsis, sp pada lahan satu (F1) terdapat 7 pohon (35\%) pada lahan dua (F2) terdapat 10 pohon $(50 \%)$ pada lahan 
Jurnal Media Pertanian Vol. 3 No. 1 Tahun 2018 Hal. 24 - 31

Media Komunikasi Hasil Penelitian dan Review Literatur Bidang Ilmu Agronomi ISSN print $2503-1279$ ISSN online $2581-1606$

tiga (F3) terdapat 12 pohon (60\%) Penyakit busuk janur yang diakibatkan oleh jamur Fusarium, sp pada lahan satu (F1) terdapat 6 pohon (30\%), pada lahan dua (F2) terdapat 4 pohon (20\%), pada lahan tiga (F3) terdapat 5 pohon $(25 \%)$. Jenis penyakit yang ditemukan pada seluruh lahan yang diamati ada empat Penyakit yaitu busuk buah, layu natuna, bercak daun dan busuk janur.

Dari Tabel 1, terlihat di tiga lokasi pengambilan sampel daun tanaman kelapa dalam terdapat jamur Pestalotiopsis sp. Dari hasil pengamatan gejala Pestalotiopsis sp terdapat bercak kuning pada daun yang kemudian meluas hinga daun-daun tampak menguning. Pada daun yang terserang terdapat bercak-bercak yang tembus cahaya dan adanya area nekrosa yang tampak kering pada bagian tengahnya, berbintik-bintik kecil (cairan) yang berwarna hitam yang disebut acervuli jamur. Bercak-bercak dapat bersatu sehingga membentuk bercak yang besar. Schuster (2012 ) menyatakan penyakit ini biasanya menyerang dimulai dari ujung daun dan berkembang kearah pangkal daun. Warna daun berubah dari hijau menjadi kekuning-kuningan, kemudian cokelat gelap atau hampir hitam. Persentase serangan penyakit ini lebih banyak di 3 lokasi dibandingkan penyakit penyakit yang disebabkan jamur Fusarium sp, hal ini disebabkan oleh tingginya patogenisitas dari jamur Pestalotiopsis sp.

Penyakit busuk janur menyebabkan gejala bercak-bercak tembus cahaya pada permukaan daun, kemudian segera menjadi cokelat kekuning-kuningan yang sering bersatu membentuk bercak berukuran lebih besar (Yudirachman, 2016). Sedangkan busuk buah pada kulit (epikarpium) terjadi bercak kecil, berwarna coklat muda basah-kebasahan, dengan garis tengah lebih kurang $1 \mathrm{~cm}$, biasanya pada pertengahan antara ujung dan pangkal buah, biasanya buah akan gugur jika bercak mencapai kelopak (tudung bunga) perkembangan bercak cokelat cukup cepat sehingga dalam waktu beberapa hari seluruh permukaan menjadi busuk, basah dan berwarna cokelat kehitaman, pada kondisi lembab dipermukaan buah akan muncul serbuk berwarna putih (Bannett, Sitepu dan Roboth, 1985).

\section{Pengamatan Pertumbuhan Jamur Pada Moist chamber}

Hasil pengamatan pertumbuhan miselia jamur pada cawan petridish dapat dilihat pada Tabel 2. Pengamatan jamur dalam petridish dilakukan tiga hari sekali, mulai penanaman di media moist chamber selama 7 hari. Pengamatan bertujuan untuk melihat pertumbuhan jamur pada media moist chamber, 
Jurnal Media Pertanian Vol. 3 No. 1 Tahun 2018 Hal. 24 - 31

Media Komunikasi Hasil Penelitian dan Review Literatur Bidang Ilmu Agronomi ISSN print $2503-1279$ ISSN online $2581-1606$

\begin{tabular}{|c|c|c|c|c|c|}
\hline \multirow{2}{*}{$\begin{array}{l}\text { Pengamatan } \\
\text { Hari Ke- }\end{array}$} & \multirow{2}{*}{ Penyakit } & \multicolumn{3}{|c|}{ Sampel } & \multirow{2}{*}{ Keterangan Pertumbuhan Jamur } \\
\hline & & F1 & $\mathrm{F} 2$ & $\mathrm{~F} 3$ & \\
\hline \multirow{4}{*}{ 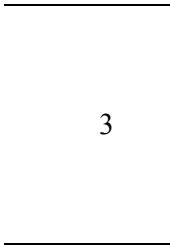 } & Busuk buah & 5 & 16 & 5 & \multirow{4}{*}{$\begin{array}{l}\text { Miselia jamur yang terlihat pada Moist } \\
\text { Chamber, namun sangat halus berwarna } \\
\text { putih. }\end{array}$} \\
\hline & Layu natuna & 1 & 9 & 1 & \\
\hline & Bercak daun & 3 & 4 & 3 & \\
\hline & Busuk janur & 9 & 19 & 9 & \\
\hline \multirow{4}{*}{5} & Busuk buah & 5 & 16 & 5 & \multirow{4}{*}{$\begin{array}{l}\text { Miselia jamur tumbuh pada Moist } \\
\text { Chamber terlihat semakin banyak, dan } \\
\text { terlihat seperti benang warna putih }\end{array}$} \\
\hline & Layu natuna & 1 & 9 & 1 & \\
\hline & Bercak daun & 3 & 4 & 3 & \\
\hline & Busuk janur & 9 & 19 & 9 & \\
\hline \multirow{4}{*}{7} & Busuk buah & 5 & 16 & 5 & \multirow{4}{*}{$\begin{array}{l}\text { Miselia jamur terlihat banyak, dan } \\
\text { menutupi ex-plan tanaman. Warnanya } \\
\text { pun berubah kecoklatan. }\end{array}$} \\
\hline & Layu natuna & 1 & 9 & 1 & \\
\hline & Bercak daun & 3 & 4 & 3 & \\
\hline & Busuk janur & 9 & 19 & 9 & \\
\hline
\end{tabular}

Pertumbuhan jamur pada buah dan daun di media moist chamber mengalami peningkatan dengan pertambahan hari. Menurut Ganjar (2006) jamur dapat tumbuh baik dengan kelembaban 80-90 \% dengan suhu optimum $25-30{ }^{\circ} \mathrm{C}$, namun ada sebagian jamur bersifat psikotrofik yang mampu tumbuh pada suhu lemari es.

\section{Jenis Jamur Patogen Yang Teridentifikasi Secara Mikroskopik Fusarium sp.}

Hasil pengamatan mikroskopis Jamur Fusarium sp. mempunyai 2 jenis konidia yaitu, makrokonidia dan mikrokonidia. Makrokonidia berbentuk memanjang dan membengkok dengan ujung yang meruncing bersel 3-6, ada juga mikrokonidia tidak mempunyai sekat, tapi ada yang mempunyai dua sekat, berbentuk elips lurus atau sedikit melengkung. Hal ini sesuai dengan pendapat Gandjar et al. (1999) yang menyatakan bahwa mikrokonidia umumnya tidak mempunyai sekat tetapi ada yang bersekat dua, terdapat dalam jumlah yang banyak sekali, berbentuk ovoid-elips sampai silindris, lurus atau sedikit membengkok.

Menurut Semangun (1991) penyebaran spora disebabkan oleh percikan air hujan. Percikan air mengenai jamur Fusarium, sp yang menginfeksi bagian tanaman yang berada di daerah yang lebih tinggi. Jamur membentuk banyak konidium pada jaringan yang terkena percikan air yang membawa patogen jamur, terlebih jika udara sangat lembab pertumbuhan patogen jamur akan semkin cepat. Untuk mengendalikan penyakit yang diakibatkan jamur Fusarium, sp dapat dilakukan penyemprotan menggunakan Perenox, Dithane M-45, Captan, dan berbagai merek dagang Fungisida lainnya. 
Jurnal Media Pertanian Vol. 3 No. 1 Tahun 2018 Hal. 24 - 31

Media Komunikasi Hasil Penelitian dan Review Literatur Bidang Ilmu Agronomi ISSN print $2503-1279$

\section{Pestalotiopsis sp.}

Hasil pengamatan mikroskopis diketahui bahwa konidium Pestalotiopsis sp ini berbentuk bersekat 4 dan mempunyai 3 seta (rambut) apical. Hal ini sesuai dengan pernyataan Sumardiyono dan Triharso (1985) dalam Semangun (2008) yang menyatakan bahwa konidium jamur Pestalotiopsis, sp berbentuk kumparan, bersekat 4, mempunyai 3 seta (rambut) apical.

Menurut Semangun (1991), spora jamur tersebar karena terbawa oleh angin, untuk jarak yang dekat dapat terbawa oleh air dan serangga. Spora jamur Pestalotiopsis, sphanya dapat menginfeksi jika ada bagian tanaman yang terluka pada daun. Penyakit yang diakibatkan oleh jamur Pestalotiopsis, sp lebih banyak terdapat pada tanaman yang kurang baik pertumbuhannya. Kelebihan nitrogen dan penggunaan pupuk kandang yang berlebihan membuat tanaman akan lebih rentan terserang penyakit.

Pengendalian penyakit yang diakibatkan oleh jamur Pestalotiopsis, sp yaitu dengan aplikasi pupuk kalium. Aplikasi pupuk kalium dapat meningkatkan ketahanan tanaman terhadap serangan penyakit. Pada pembibitan dapat dilakukan penyemprotan fungisida dan insektisida.

\section{Hasil Wawancara Tindakan Agronomi Dengan Petani}

Berdasarkan hasil wawancara langsung di lapangan terdapat sedikit perbedaan tindakan agronomi antar petani, yang dirangkum pada Tabel 3.

Tabel 3. Data hasil wawancara dengan petani

\begin{tabular}{|c|c|c|c|c|c|}
\hline \multirow[t]{2}{*}{ No. } & \multirow{2}{*}{\multicolumn{2}{|c|}{ Kuisioner }} & \multicolumn{3}{|c|}{ Petani Kelapa Dalam } \\
\hline & & & Petani F1 & Petani F2 & Petani F3 \\
\hline 1 & Nama & & Tardjo & Kasmiran & Suhardi \\
\hline 2 & Umur (Tahun) & & 53 & 50 & 55 \\
\hline 3 & Pendidikan Akhir & & SD & SD & SD \\
\hline 4 & Luas Areal Tanaman Kelapa & & 1 Hektar & 1 Hektar & 1 Hektar \\
\hline 5 & Jarak Tanam & & $8 \times 7 \mathrm{~m}$ & $8 X 7 \mathrm{~m}$ & $8 \times 7 \mathrm{~m}$ \\
\hline 6 & Pengolahan Lahan & & $\begin{array}{l}\text { Penebasan rumput, } \\
\text { penyemprotan } \\
\text { menggunakan } \\
\text { pestisida }\end{array}$ & $\begin{array}{l}\text { Penebasan rumput, } \\
\text { penyemprotan } \\
\text { menggunakan } \\
\text { pestisida dan } \\
\text { pembuatan } \\
\text { drainase } \\
\text { anak) }\end{array}$ & $\begin{array}{l}\text { Penebasan } \\
\text { rumput, } \\
\text { penyemprotan } \\
\text { menggunakan } \\
\text { pestisida dan } \\
\text { pembuatan } \\
\text { drainase (parit } \\
\text { anak) }\end{array}$ \\
\hline 7 & $\begin{array}{l}\text { Pemeliharaan Tanaman Yang } \\
\text { Lakukan }\end{array}$ & Di & $\begin{array}{l}\text { Pengendalian } \\
\text { gulma dengan cara } \\
\text { penebasa dan } \\
\text { penyemprotan } \\
\text { dengan pestisida }\end{array}$ & $\begin{array}{l}\text { Pengendalian } \\
\text { gulma dengan cara } \\
\text { penebasa dan } \\
\text { penyemprotan } \\
\text { dengan pestisida }\end{array}$ & $\begin{array}{l}\text { Pengendalian } \\
\text { gulma dengan } \\
\text { cara penebasa } \\
\text { dan } \\
\text { penyemprotan } \\
\text { dengan } \\
\text { pestisida }\end{array}$ \\
\hline
\end{tabular}

Tabel 3, menunjukkan petani kelapa dalam secara umum menggunakan jarak tanam $8 \times 7 \mathrm{~m}$, alasannya memudahkan dalam pengendalian gulma yang ada. Pemeliharaan tanaman yang dilakukan petani hanya pengendalian gulma saja sedangkan untuk pengendalian hama dan penyakit tidak dilakukan. Pengetahuan petani tentang penyakit pada tanaman kelapa dalam rendah dan tidak ada perlakuan pencegahan terhadap penyakit. Kebanyakan petani menggunakan bibit hasil semaian sendiri. Pemupukan pada tanaman kelapa dalam tidak pernah dilakukan. 
Jurnal Media Pertanian Vol. 3 No. 1 Tahun 2018 Hal. 24 - 31

Media Komunikasi Hasil Penelitian dan Review Literatur Bidang Ilmu Agronomi ISSN print $2503-1279$ ISSN online $2581-1606$

KESIMPULAN

Berasarkan hasil penelitian maka dapat disimpulkan bahwa ditemukan 2 (dua) jenis patogen yang menyerang tanaman kelapa dalam di Desa Sungai Jereng Kecamatan Pengabuan Kabupaten Tanjung Jabung Barat yaitu, Fusarium, sp yang merupakan patogen penyakit busuk buah, layu natuna dan busuk janur dan Pestalotiopsis sp penyebab penyakit bercak daun.

\section{DAFTAR PUSTAKA}

Bennett.C.P.A., G. Sitepu, and O. Roboth (1985), Aspects Of The Control Of Premature Nutfall Disease On Coconut Caused By Phytophthora Palmivora (Butl.) Butl. Seminar Prot. Tan. Kelapa, Bogor, Mei 1985.

Barnett, H. L. 1974. Illustrated Genera of Imperfect Fungi. Burgess Publishing Company, West Virginia.

Dinas Perkebunan. 2015. Luas dan Produksi Tanaman Perkebunan Provinsi Jambi Menurut Kabupaten. Jambi.

Dinas Perkebunan. 2014. Luas Dan Produksi Tanaman Perkebunan Tanjung Jabung Barat Menurut Kecamatan.

Gandjar, I et al. 2006. Mikologi Dasar Dan Terapan. Jakarta: Yayasan Obor Indonesia.

Gandjar, I., Robert, A. S., Karin, V., Ariyanti, O., Iman, S. 1999. Pengenalan Kapang Tropik Umum. Universitas Indonesia, Depok.

Ruauw, E. Baroleh, J dan Powa D. 2011. Kajian Pengelolaan Usahatani Kelapa Di Desa Tolombukan Kecamatan Pasan Kabupaten Minahasa Tenggara.

Schuster J. 2012. Pestalotiopsis Blight. Universitas of Illinois at Urban, Champaign

Semangun, H. 1991. Penyakit Tanaman Pekebunan di Indonesia. Gajah Mada Universitas Press Jogyakarta. . 2008. Penyakit-Penyakit Tanaman Perkebunan di Indonesia (Edisi kedua). Gadjah Mada University Press, Yogyakarta.

Tasri, E. S. 2007. Metodologi Penelitian Ekonomi Dan Bisnis. Universitas Bung Hatta. Padang.

Yudirachman, H. 2016. Untung Berlipat Dari Budidaya Kelapa Tanaman Multi Manfaat. 